Отримано: 25 листопада 2018 р.

Прорецензовано: 20 грудня 2018 р.

Прийнято до друку: 21 грудня 2018 р.

e-mail: valerymykhaylenko@i.ua

DOI: $10.25264 / 2519-2558-2018-4(72)-74-77$
Mykhaylenko Valery. Semantic metamerism: ethno-cultural aspect. Наукові записки Наиіонального університету «Острозька академія»: серія «Філологія». Острог : Вид-во НаУОА, 2018. Вип. 4(72), грудень. С. 74-77.

\author{
Valery Mykhaylenko, \\ Doctor of Philology, professor, Institute of International Relations and Social Studies, MAUP, Kyiv
}

УДК 811.111 '367.628

\title{
SEMANTIC METAMERISM: ETHNO-CULTURAL ASPECT
}

This paper is a contextual study of English black colour term - its etymology, dynamics of the lexical meaning and its ability to reveal controversial components in the corresponding context The analysis is based on the dictionary entries and advertising fragments as actualizers of the referred components. Here contextual is used loosely in the sense that the colour terms are not analysed in isolation but in conjunction with other linguistic units. The overall aim of the study is to describe and analyse a number of aspects of the semantics of English colour terms within the framework of cognitive linguistics. Colour metamerism is the phenomenon wherein two colored samples will appear to be of the same shade under one light source but will appear to be different shades under a second source. In linguistics such colour terms are discussed in the framework of enantiosemia as the intra-word ability to express antonymic relationship. It is also may be interpreted as an intra-word antonymy. The purpose of the article is three-fold: to examine (1) the componential structure of the lexical meaning of the black colour term including its etymology and dynamic semantics; (2) the compositionality of the black with the names of some week days; and (3) the formation of colour metamerisms in English. We put forward a hypothesis according to which the original colour name undergoes dynamic semantic changes and generates controversial components. At present it combines two types of polar components in its lexical meaning, decoding of the respective one by the addressee depends on his/her background knowledge and type of discourse - in our case-economy.

Key words: metamerism, colour nomination, enantiosemia, dynamic semantics, lexical meaning, context, discourse.

\author{
Михайленко Валерій Васильович, \\ Доктор філології, професор, Інститут міжнародних відносин і соиіальних наук МАУП, Київ
}

\section{СЕМАНТИЧНИЙ МЕТАМЕРІЗМ: ЕТНО-КУЛЬТУРНИЙ АСПЕКТ}

Мета статті потрійна: розглянути (1) компонентну структуру лексичного значення чорного кольору, включаючи ї̈ етимологію та динамічну семантику; (2) сполучуваність чорного кольору з назвами певних днів тижня та (3) розвиток лексеми чорний колір у метамерізм в англійській мові. Згідно нашої гіпотези оригінальна назва чорного кольору зазнає динамічних семантичних змін у результаті яких породжуються полярні компоненти. В даний час зазначена назва поєднує два типи полярних компонентів у його лексичному значенні, а декодування відповідного компоненту залежить від фонового знання адресату та типу дискурсу - в нашому випадку - економіки.

Ключові слова: метамерізм, кольоризм, динамічна семантика, енантосемія, лексичне значення, контекст, дискурс.

PRELIMINARIES. The human eye can perceive millions of different colors, but the number of categories human languages use to group those colors is much smaller. Some languages use as few as three color categories (words corresponding to black, white, and red), while the languages of industrialized cultures use up to 10 or 12 categories. Colour metamerism is the phenomenon wherein two coloured samples will appear to be of the same shade under one light source but will appear to be different shades under a second source. In metamerism there is a perceived matching of the colours that, based on differences in spectral power distribution, do not actually match. Colours that match this way are called metamers. The term metamerism is used to describe colors that match under a specific light source, but do not match under all light sources. It is primarily caused by the use of different pigments to achieve the colors. A spectral power distribution describes the proportion of total light given off (emitted, transmitted, or reflected) by a colour sample at each visible wavelength; it defines the complete information about the light coming from the sample (Technical Manual Glossary, 2015). However, the human eye contains only three colour receptors (three types of cone cells), which means that all colours are reduced to three sensory quantities, called the tristimulus values. Metamerism occurs because each type of cone responds to the cumulative energy from a broad range of wavelengths, so that different combinations of light across all wavelengths can produce an equivalent receptor response and the same tristimulus values or colour sensation. In colour science, such sensations are numerically represented by colour matching functions.

Don Dedrick [10, p. 497] writes that in Brent Berlin and Paul Kay's Basic colour terms [7] built on earlier work Lenneberg [16, p. 320], there is a continuing debate as to existing linguistic universals in the restricted domain of colour naming. But there is a need of an adequate conceptual account of how people may come to have and use basic colour terms-an account which stands between the biological and the cultural. And the author's main contention is that the central problems with the Berlin-Kay tradition arise from the difficulty of linking conceptually and empirically disparate domains: linguistic, psychological, physiological. The basic colour terms for English are: white, black, red, green, yellow, blue, brown, grey, purple, pink and orange. These terms are generally believed to refer to colour categories. Each category has a focal colour which is the dominant of a particular colour category [8, p.5.]. In physics, a color is visible light with a specific wavelength. Black is not a colour because it does not have specific wavelengths, it is the absence of visible light (Britannica). The colour terms like black which are able to actualize controversial components of their lexical meaning were traditionally related to enantiosemia. In English the usual grading of the simple colours are expressed with the following markers: the suffix -ish, the adverbs very, much, more, most and little, less, least -- their compositionality with the term black in the phrase, for instance, Black Friday is not registered.

The purpose of the article is three-fold: to examine (1) the componential structure of the lexical meaning of the black colour term including its etymology and dynamic semantics; (2) the compositionality of the black with the names of some week days; (3) the 
formation of colour metamerisms in English. We put forward a hypothesis according to which the original colour name undergoes dynamic semantic changes and generates controversial components. At present it combines two types of polar components in its lexical meaning, decoding of the respective one by the addressee depends on his/her background knowledge and type of discourse - in our case - economy.

THEORETICAL GROUNDING. Enantiosemia is considered to be the intra-word ability to express antonymic relationship which can be called an intra-word antonymy. Its formal indicator, L.A. Novikov stresses, is a syntactic and lexical compositionality of the word in its polar meanings [2, p.29]. However, H.M. Shansky denies that there are intra-word antonyms, rather they represent a type of homonyms [3, p.64]. B.T. Ganeyv suggests that the term enantionym defines the words with two controversial components whose verbalizing depends upon the author's intention and the type of the context [cm. 1, p.9fl.]. In our opinion the concept of enantiosemia resorts to the causes and consequences of the language changes. Besides, it is an interdisciplinary phenomenon of semantics, cognition, and some extra-linguistic factors in the life of the society which are crucial for the recipient to understand. We introduce the term of metamerism which represents the linguistic sign having two polar components in its semantic nucleus.

The adjective black refers to the domain of colour which differentiates between basic and combinatory [see 4, p.135; 6, p,19-20]. As Joris Bleys writes that only «a small minority (around 15\%) of all colour samples would be described using a single colour term [18; Lin et al. 15]. Most samples are described using more elaborate expressions, for example by using modifiers or combinations of colour terms [8, p. xi]. Black in our study is a basic colour term used single without any grading words as an adjunct in the phrase with the name of the day as the head word. Although the domain of colour might be fairly restricted, it is fascinating to see how different languages around the world use different language strategies to express it. Semantic domains represent conceptual systems in the worldview, like general existence, habitat, time, space, or more concrete like dwelling, leisure, colour, etc. which reveal cohesion due to the common component in their lexical meaning. Semantic domains have two major functions, first, linking words as a lexical unity in the lexicon and, second, assigning retrieved texts to a certain concept or area which serves as an organizing formative of a corpus. If «colour, in a western technical sense, is not a universal concept, H.C. Conkin writes, then in many languages there is no unitary terminological equivalent» [9, p.931]. J.A. Lucy stresses that ithout such a term, one cannot attribute «colour» as a concept to a language [16, p.329-330]. It is a linguistic category expressed by a linguistc sign attributing the concept to the semantic system of the language.

CORPUS ANALYSIS. Cognitive semantics embraces a conceptualist view of meaning, where meaning is claimed to be encyclopedic in nature. An important consequence of this view is that the meaning of any lexeme is in principle open-ended, since it may, in the individual speaker, evoke any kind of association [19, p.41]. The background knowledge which serves as the ground for a

predication (the figure) is called a cognitive domain, or shorter, domain. In R.W. Langacker's view a domain is a conceptualisation of any sort and of any kind of complexity against which a meaning is created. The scholar makes a fine distinction between different types of domains [14]. Most domains, like colour terms, presuppose other underlying domains, for instance, basic colours or three: red, yellow, blue; three secondary: orange, green, violent; and six tertiary: red-orange, yellow-orange, yellow-green, bluegreen, blue-violet, red-violet, which are formed by mixing a primary with a secondary and, so that a particular predication can be built on an advanced structure of domains. The colour tempreture can also subclassify colours into warm and cool colours [5]. In physics black and white are not colors because they do not have specific wavelengths. Instead, white light contains all wavelengths of visible light, black, on the other hand, is the absence of visible light (Britannica).

We shall start with the ETYMOLOGY of black (adj.): Old English bloec «absolutely dark, absorbing all light, the color of soot or coal,» from Proto-Germanic *blakaz «burned» (source also of Old Norse blakkr «dark,» Old High German blah «black,» Swedish bläck «ink,» Dutch blaken «to burn»), from PIE *bhleg- «to burn, gleam, shine, flash» (source also of Greek phlegein «to burn, scorch,»Latin flagrare «to blaze, glow, burn»), from root *bhel- (1) «to shine, flash, burn.»The same root produced Old English blac «bright, shining, glittering, pale;» the connecting notions being, perhaps, «fire» (bright) and «burned» (dark), or perhaps «absence of color.» «There is nothing more variable than the signification of words designating colour» [Wedgwood]. Anders points that black is registered in the year of 700. [5, p.263]. The usual Old English word for «black» was sweart (see swart). According to OED: «In ME. it is often doubtful whether blac, blak, blake, means 'black, dark,' or 'pale, colourless, wan, livid.' «Used of darkskinned people in Old English.

And then we shall follow the approach of Dynamic Semantics as a perspective on natural language semantics that emphasizes the expansion of the word lexical meaning due to the growth of information in time. It is an approach to meaning representation where the corpus of texts or discourses provides the contexts actualizing new components of the word lexical meaning [cf. Stanford Encyclopedia of Philosophy]. The OED uses chronology when registering new components verbalized by the word: of coffee with nothing added, attested by 1796. Black drop (1823) was a liquid preparation of opium, used medicinally. Black-fly (c. 1600) was used of various insects, especially an annoying pest of the northern American woods. Black Prince as a nickname of the eldest son of Edward III is attested by $1560 \mathrm{~s}$; the exact signification is uncertain. Meaning «fierce, terrible, wicked» is from late 14c. Figurative senses often come from the notion of «without light,» moral or spiritual. Latin niger had many of the same figurative senses («gloomy; unlucky; bad, wicked, malicious»). The metaphoric use of the Greek word, melas, however, tended to reflect the notion of «shrouded in darkness, overcast.» In English it has been the color of sin and sorrow at least since c. 1300; the sense of «with dark purposes, malignant» emerged 1580s (in black art «necromancy;» it is also the sense in black magic). Black flag, flown (especially by pirates) as a signal of «no mercy,» is from 1590s. Black dog «melancholy» attested from 1826 . Black belt is from 1870 in reference to district extending across the U.S. South with heaviest African population (also sometimes in reference to the fertility of the soil); it is attested from 1913 in the judo sense, worn by one who has attained a certain high degree of proficiency. Black power is from 1966, associated with Stokely Carmichael. Black English «English as spoken by African-Americans,» is by 1969. The Black Panther (1965) movement was an outgrowth of Student Nonviolent Co-ordinating Committee. Black studies is attested from 1968 (OED Online. http://dictionary.oed.com). Merriam-Webster's definition of black, (adjective): (1) of the color black; (2)very dark in color; (3) having a very deep or low register) a bass; (4) heavy, serious; (5) having dark skin, hair, and eyes; (6) of or relating to any of various population groups having dark pigmentation of the skin or their culture; (7) dressed in black; (8) dirty, soiled; (9) characterized by the absence of light; (10) reflecting or transmitting little or no light; (11) served without milk or cream; (12) thoroughly 
sinister or evil; (13) indicative of condemnation or discredit; (14) connected with or invoking the supernatural and especially the devil; (15) very sad, gloomy, or calamitous; (16) marked by the occurrence of disaster [Black Friday]; (17) characterized by hostility or angry discontent; (18) chiefly British : subject to boycott by trade-union members; (19) of propaganda: black radio, black humor, black government programs. Cf: The definition of black adj. (1) having the darkest colour; (2) without any milk or cream added; (3) evil; (4) without hope; (5) bad or evil: a black-hearted villain (Cambridge). The negative component of disaster in the meaning of Black Friday is registered in the dictionaries, however we shall use the various registers of discourse to decode new positive components:

The Evolution of the concept of Black Friday and the formation of the metamerism black. The lexical meaning of the adjective $B L A C K$ retaining its negative component actualizes a new positive component in an alien discourse NEGATIVE + POSITIVE (SHOPPING) or 'PROFITABLE' which goes back to accounting: (1)The term black is used to refer to a company's profitability. A company is said to be «in the black» if it is profitable or, more specifically, if the company produces positive earnings after accounting for all expenses. Conversely, a company with negative earnings would be said to be «in the red.» (Investopedia)

(2) Black Friday which refers to the day after the U.S. Thanksgiving, a traditional holiday is a day-off, full of special deals and heavy discounts. It is considered the kickoff of the holiday shopping season before Christman. Some say the day is called «Black Friday» in homage to the term «black» referring to being profitable, which stems from the old bookkeeping practice of recording profits in black ink

(3) However, long before it started appearing in advertisements and commercials, the term was actually coined by overworked Philadelphia police officers. In the 1950s, crowds of shoppers and visitors flooded the City of Brotherly Love the day after Thanksgiving. (4) The term quickly gained popularity and spread to store salespeople who used Day sales started long before the day was actually coined «Black Friday.» (5) Black Friday $\diamond$ Black Weekend became the frenzied, over-the-top shopping event it is today in the 2000s. Until then, that title had gone to the Saturday before Christmas. Black Friday is becoming an increasingly lengthy event $\checkmark$ a Black Weekend. (6) BLACK FRIDAY $\diamond$ BLACK THURSDAY. In 2013 Target announced that instead of opening their doors on Friday morning, they would now be starting sales Thanksgiving. More recently Black Friday $\diamond$ Black Thursday is also used to refer to the Thanksgiving holiday in the United States, as more retailers open on Thanksgiving evening in a bid to get an early start on the frenzied shopping of Black Friday [see the correlation of colour and culture: 11].

The adjective black actualizes its negative component as dominant in the phrases Black Friday, Black Monday, and Black Thursday when they are used in the Economics Discourse or its registers, like banking, finance, industry, world trade, stock market, etc. (1) In history, Black Friday was a stock market catastrophe that took place on Sept. 24, 1869. On that day, after a period of rampant speculation, the price of gold plummeted and the market crashed. Since a new component in the meaning of the phrase Black Friday «market catastrophe « has stabilized and other days on which the same catastrophe occurred employed the ready-made semantic cliché. Here we can observe the traditional metonymy which hinges on the two 'things' being closely related. A figure of speech which consists in substituting for the name of a thing the name of an attribute of it or of something closely related [OED: metonymy; see also 13, p.20]. (2) Black Thursday is the name given to Thursday, Oct. 24, 1929, when the Dow Jones Industrial Average plunged 11 percent at the open in very heavy volume, precipitating the Wall Street crash of 1929 and the subsequent Great Depression of the 1930s. It is also often used to describe Stock Market Crash, disastrous days, in financial markets. For example, on Black Tuesday, Oct. 29, 1929, the market fell precipitously, signaling the start of the Great Depression. (3) On Black Monday (Oct. 19, 1987) occurred the largest one-day drop in stock market history, when the Dow Jones Industrial Average plummeted more than $22 \%$ in a single day. The event marked the beginning of a global stock market decline, and Black Monday became one of the most notorious days in financial history. By the end of the month, most of the major exchanges had dropped more than 20\%. (4) Here is an example of true metamerism when one the same day for the shoppers is an adventure followed by some profit and for the policemen Black Friday is a dreaded workday for traffic policemen who were required to work 12-hour shifts to deal with the throngs of drivers and pedestrians, and they were not allowed to take the day off.

Anders Steinvall specifies the frequency of the adjective black used in the OED which co-occurs with the semantic domains of nouns denoting: deseases $=16$, plants $=51$, animals $=36$; human related: parts of a body $=6$; clothes $=10$; other $=13$; artifacts: concrete $=35$; abstract $=7$; figurative use $=16$. Total $=218[18, \mathrm{p} .114,120]$. Though he does not differentiate the compositionality of $b l a c k$ with names of certain days of November which happens to be in a swirl of Black-Blacker Blackest colour of advertizing not only in the USA. The concept of Black Friday is widely employed by marketing of many countries. And due its profitability you can find an add, like 'We have Black Friday every day» or 'Black Friday every week.'

FINDINGS AND PERSPECTIVES. We have attempted that the meaning of the colour term is not reducible to denotation but is also a function of and a determinant of structural position in the phrase, sentence, discourse.

Now we recognize that colour is not «out there» in the light, but in our perceptual interpretation of light. Language reflects conceptualizations, not the «neural representation of colour ... in the pathways between the eye and brain» [7].

The link between the neural representation of colour and the linguistic representation of colour can only be indirect, says Anna Wierzbicka [21, p.99fl.]. And it is time to recognize that the communicatively relevant encodings of visual experience do not lie «in there» in the biology but mostly out in socially anchored linguistic systems, for instance, the same Black Friday is a tiresome day for the traffic policemen and it is a felicitous adventures for throngs of shoppers[see also $16, \mathrm{p} .341 ; 12$ ].

Cultural groups throughout the world talk about colour differently-in the North America negative and positive components co-exist, for example, in the lexical meaning of the adjective black when it is combined with the names of certain weekdays, unlike in Ukraine and Russia where since ancient times (see folklore) the black colour has been symbolizing evil, death, tragedy, anguish, etc. However, the commercials in various media make consumers perceive Black Friday as a shopping adventure, because the component of a financial/economic tragedy has not left a deep imprint on Russians and Ukrainians, see: this new component has not found its entry, for instance, in the Academic Dictionaries of either the Ukrainian Language or of the Russian Language yet.

The development of a new subsystem of metamerisms in the vocabulary is being created under the ethnic cultural changes in the society that requires a great volume of the corpus of Contemporary English. 


\section{References:}

1. Ганеев Б. Т. Первоначальная энантиосемия и диффузность в языке. Вестник ОГУ. Гуманитарные науки. 2003. № 4. С.9-15.

2. Новиков Л. А. Лингвистическое толкование художественного текста. Москва: Русский язык, 1979. 256c.

3. Шанский Н. М. Лексикология современного русского языка. Москва: Просвещение, 1964. 316c.

4. Adams F. M., Osgood C. E. A Cross-Cultural study of the affective meanings of Color. Journal of Cross-Cultural Psychology. 1973. Vol. 4. No. 2. P. 135-156.

5. Anderson Wendy, et al.(eds.). Colour Studies: A broad spectrum. Amsterdam / Philadelphia: John Benjamins Publishing Company, 2014. 417 p.

6. Averill E. Why Are colour terms primarily used as adjectives? The Philosophical Quarterly. 1980. Vol. 30. No. 118. P. 19-33.

7. Berlin B. Kay P. Basic color terms: their universality and evolution. Berkeley: University of California Press, 1969. xi+178 p.

8. Bleys Joris. Language strategies for the domain of colour. Computational Models of Language Evolution 3. Berlin: Language Science Press, 2015. $241 \mathrm{p}$.

9. Conkin H.C. Color categorization: review of Basic Color Terms, by Brent Berlin and Paul Kay. American Anthropologist. 1973. Vol.75. P. 931-942.

10. Dedrick Don. Color language universality and evolution: On the explanation for basic color terms. Philosophical Psychology 1996. Vol. 9 (4). P. 497-524.

11. Gage J. Colour and culture: Practice and Meaning from Antiquity to Abstraction. Waterfoot: Thames and Hudson Ltd 1995.395 p.

12. Hardin C.L., Maffi L. (eds.) Colour categories in thought and language. Cambridge: Cambridge University Press, 1997.416 p.

13. Lakoff G., Johnson M. Metaphors we live by. Chicago: U. of Ch. P. 2003.191p.

14. Langacker R.W. Foundations of Cognitive Grammar. Vol. 1. Theoretical Prerequisites. Stanford: Stanford University Press, 1987. $\mathrm{x}+516 \mathrm{p}$.

15. Lin H., Luo M. R., MacDonald L. W., Tarrant Arthur W.S. A cross-cultural colour-naming study. Part I: Using an unconstrained method. COLOR research and application. 2001. Vol. 26. P. 40-60.

16. Lucy J. A. The linguistics of «color». / Ed. C.L. Hardin, L. Maffi. Color categories in thought and language. Cambridge: CUP, 1997. P. $320-346$.

17. Malkmjaer Kristen, Andersen James M. The Linguistics encyclopedia. London / New York: Routledge, 1995.795 p.

18. Simpson Jean, Tarrant Arthur W.S. Sex- and age-related differences in colour vocabulary. Language and Speech. 1991. Vol. 34(1). P. 57-62.

19. Steinvall Anders. English colour terms in context. Omslag: Umeå Universitet, 2002. 263 p.

20. Wikforss Asa. Colour terms and semantic externalism. Croatian Journal of Philosophy. 2012. Vol.12 (3). P. 399-420.

21. Wierzbicka Anna. The meaning of colour terms: Semantics, culture and cognition. Cognitive Linguistics. 1990. Vol.1 (1). P. 99-149. 